\title{
Initiation, Labile, and Stabilization Phases of Experience-Dependent Plasticity at Neocortical Synapses
}

\author{
Jing A. Wen, Mark C. DeBlois , and Alison L. Barth \\ Department of Biological Sciences and Center for the Neural Basis of Cognition, Carnegie Mellon University, Pittsburgh, Pennsylvania 15213
}

\begin{abstract}
Alteration of sensory input can change the strength of neocortical synapses. Selective activation of a subset of whiskers is sufficient to potentiate layer 4-layer 2/3 excitatory synapses in the mouse somatosensory (barrel) cortex, a process that is NMDAR dependent. By analyzing the time course of sensory-induced synaptic change, we have identified three distinct phases for synaptic strengthening in vivo. After an early, NMDAR-dependent phase where selective whisker activation is rapidly translated into increased synaptic strength, we identify a second phase where this potentiation is profoundly reduced by an input-specific, NMDAR-dependent depression. This labile phase is transient, lasting only a few hours, and may require ongoing sensory input for synaptic weakening. Residual synaptic strength is maintained in a third phase, the stabilization phase, which requires mGluR5 signaling. Identification of these three phases will facilitate a molecular dissection of the pathways that regulate synaptic lability and stabilization, and suggest potential approaches to modulate learning.
\end{abstract}

\section{Introduction}

Neocortical synapses are modified by experience, a process that can occur throughout the lifetime of an animal but is especially pronounced during early postnatal development (Crair and Malenka, 1995; Kirkwood et al., 1995; Feldman et al., 1998; Hensch, 2005; Wen and Barth, 2011). Because alterations in neocortical circuits are thought to underlie long-term memories (McClelland, 1998; Wiltgen et al., 2004), the cellular and molecular pathways required for synaptic plasticity in this area have been of great interest. Of critical importance is identifying the specific brain area and set of synapses that have been altered by experience, a criterion that has been perhaps best met by analyses in primary sensory cortex. Here we employ selective whisker activity to investigate the procession of changes in excitatory synaptic strength at layer 4 inputs on layer $2 / 3$ pyramidal cells.

The organization of facial vibrissae is recapitulated in somatotopically precise columns in the barrel cortex, an arrangement that facilitates unequivocal identification of the cortical representation of each whisker (Feldman and Brecht, 2005). This feature has been exploited in many in vitro studies to evaluate synaptic

Received July 24, 2012; revised April 1, 2013; accepted April 5, 2013.

Author contributions: J.A.W., M.C.D., and A.L.B. designed research; J.A.W. and M.C.D. performed research; J.A.W. and M.C.D. analyzed data; J.A.W. and A.L.B. wrote the paper.

This work was supported by a Grant DA-0171-88 from the National Institutes of Health. We thank Joanne Steinmiller for expert animal care, and members of the Barth laboratory for helpful discussions and comments on this manuscript. We also thank Bronwyn Woods and Linqiao Zhao for help with application of the generalized linear mixed model for statistical analysis between animal groups.

A patent is pending on the fosGFP transgenic mice by A.L.B.

Correspondence should be addressed to Alison L. Barth, Carnegie Mellon University, 4400 Fifth Avenue, Pittsburgh, PA 15213. E-mail: barth@cmu.edu.

M.C. DeBlois' present address: Department of Biological Sciences, Marshall University, 1 John Marshall Drive, Huntington, WV 25755

DOI:10.1523/JNEUROSCI.3575-12.2013

Copyright $\odot 2013$ the authors $\quad 0270-6474 / 13 / 338483-11 \$ 15.00 / 0$ plasticity induced by whisker manipulation in vivo (Finnerty et al., 1999; Takahashi et al., 2003; Bender et al., 2006; Jiao et al., 2006; Clem et al., 2008; Hardingham et al., 2008; Dachtler et al., 2011; Jacob et al., 2012).

Previously we have shown that selective whisker removal (leaving only a single whisker on one side of the snout) selectively strengthens synapses in the spared barrel column within $24 \mathrm{~h}$ of altered sensory input (Clem and Barth, 2006). The rules that govern this plasticity are complex, where NMDA receptors (NMDARs) are required first for the potentiation of spared whisker inputs at layer $4-2 / 3$ synapses, but then mediate synaptic depression (Clem et al., 2008). NMDAR-mediated decay of synaptic potentiation has been observed in other systems, such as the hippocampus (Villarreal et al., 2002; Qi et al., 2013), suggesting that this transition in NMDAR function might occur across multiple synapse types in the brain.

To understand how experience might persistently alter neocortical synapses, we monitored synaptic potentiation induced by sensory activity at short time intervals. Within a few hours following selective whisker removal, layer $4-2 / 3$ synapses in the spared barrel column grow significantly stronger, reaching their peak amplitude after $12 \mathrm{~h}$ of altered whisker experience. After this initiation phase, sensory input triggers an NMDAR-dependent reduction in synaptic strength, specifically at recently potentiated synapses. This labile phase is transient, lasting $\sim 12 \mathrm{~h}$, before synapses are stabilized at a new, larger amplitude compared with control animals.

After the termination of the labile phase, increases in synaptic strength appear to be stabilized in a process that requires signaling via mGluR5. These multiple phases of synaptic plasticity may be common across many types of excitatory synapses in the CNS, and will provide a platform for analysis of the specific molecular changes that occur during experience-dependent modification of synaptic function. In addition, these results suggest strategies for 
"memory" modification, using both pharmacological and behavioral approaches to regulate synaptic strength.

\section{Materials and Methods}

Animals. Two sensory paradigms were used in this study: single whisker experience (SWE) versus single row experience (SRE). In the SWE paradigm, bilateral whisker deprivation was performed where all but the D1 whisker on one side of an animal's snout was plucked (Glazewski et al., 2007). In the SRE paradigm, all whiskers were deprived bilaterally except a single set of D-row whiskers on one side (Finnerty et al., 1999). Heterozygous mice from the 1-3 fosGFP line (backcrossed 12-18 generations into the C57BL6 strain purchased from Harlan) transgenic line (aged P12-P14, of either sex) were used for experiments where SWE was induced. Because no difference in Sr-EPSC amplitudes have been observed between fosGFP + and fosGFP \{minus] layer 2/3 neurons (Clem and Barth, 2006), values for all cells were grouped. More than $75 \%$ of recorded cells from transgenic mice were fosGFP-. For SRE, almost all experiments (36/40 animals) were performed in wild-type mice. Animals were returned to their home cages for varied amount of time $(0-72 \mathrm{~h})$ before recording. Control animals were whisker-intact littermates of deprived animals from the same age range (P12-P14), and included fos$\mathrm{GFP}+/-$ and fosGFP $-/$ - littermates, or were from an in-house C57BL6 colony established from Harlan. Because control animals did not undergo whisker plucking, the data from these animals are referred to as " $0 \mathrm{~h}$," to indicate the baseline response, and recordings were not restricted to a single barrel column. Whisker stimulation occurred during the course of normal animal behavior; individual whiskers were not directly stimulated by the experimenter.

Slice preparation and whole-cell recording. Animals were anesthetized with isoflurane and decapitated. Slices were prepared in two different ways according to the type of sensory experience (SWE vs SRE) that animals underwent in vivo. Coronal slices with $350 \mu \mathrm{m}$ thickness for SWE-treated animals were vibratome sectioned in artificial CSF (ACSF) at $2-6^{\circ} \mathrm{C}$ composed of the following $(\mathrm{mM}): 119 \mathrm{NaCl}, 2.5 \mathrm{KCl}, 2.5 \mathrm{CaCl}_{2}$, $1.3 \mathrm{MgSO}_{4}, 1 \mathrm{NaH}_{2} \mathrm{PO}_{4}, 26.2 \mathrm{NaHCO}_{3}$, and 11 glucose and equilibrated with $95 / 5 \% \mathrm{O}_{2} / \mathrm{CO}_{2}$. Slices from SRE-treated animals were prepared by an "across-row" protocol (Finnerty et al., 1999; Clem et al., 2010). The dissected brain was put on a flat surface (no incline) and one cut was made at the posterior end of the brain along a $45^{\circ}$ plane toward the midline (see Fig. 1A). The hemisphere contralateral to the spared whiskers was saved and the sectioning plane was mounted for slice preparation.

The barrel column representing the spared D1 whisker in SWE-treated animals was identified after at least $18 \mathrm{~h}$ SWE by enhanced fosGFP expression and relative position to the hippocampus in acute brain slices. The spared D row in SRE-treated animals was identified as the fourth barrel from the lateral side of slices that contain five barrels (Fig. 1B; barrel rows A to E, lateral to medial). Typically, one to two slices per brain contained the entire complement of five barrels.

Slices were maintained and whole-cell recordings were performed at room temperature. Somata of lower layer $2 / 3$ pyramidal neurons in barrel cortex (i.e., presumptive layer 3 ) were targeted for whole-cell recording with borosilicate glass electrodes with a resistance of 4-8 $\mathrm{M} \Omega$. Electrode internal solution was composed of the following (in mM): 130 cesium gluconate, 10 HEPES, 0.5 EGTA, $8 \mathrm{NaCl}, 10$ tetraethylammonium chloride, $4 \mathrm{Mg}$-ATP, and 0.4 Na-GTP, 5 QX-314 at pH 7.25-7.30, 290-300 mOsm and contained trace amounts of Alexa 568. Pyramidal cell identity was confirmed after the recording session by pyramidal somata morphology and the presence of dendritic spines. Only cells with $R_{\text {series }} \leq 30 \mathrm{M} \Omega$ and $R_{\text {input }} \geq 200 \mathrm{M} \Omega$, where changes in either measurement were $<30 \%$, were included for analysis. Stimulation of presynaptic afferents at $0.1 \mathrm{~Hz}$ was performed using a glass monopolar electrode placed in the center of the barrel in layer 4 . Postsynaptic responses from layer $2 / 3$ pyramidal neurons within the same barrel column were recorded. Electrophysiological data were acquired by Multiclamp 700A (Molecular Devices) and a National Instruments acquisition interface. The data were filtered at $3 \mathrm{kHz}$ and digitized at $10 \mathrm{kHz}$ and collected by Igor Pro 6.0 (Wavemetrics). Extracellular simulation was controlled by a Master-8 (A.M.P.I.) and a stimulus isolator Isoflex (A.M.P.I.).
Miniature EPSC measurements. To measure the amplitude of stimulus-evoked miniature EPSC (mEPSCs), $\mathrm{Sr}^{2+}$ ( $3 \mathrm{~mm}$ ) was substituted for $\mathrm{Ca}^{2+}$ in ACSF to drive asynchronous glutamate release. D-APV $(50 \mu \mathrm{M})$ and picrotoxin $(50 \mu \mathrm{M})$ were included to pharmacologically isolate AMPAR-mediated EPSCs. Layer $2 / 3$ pyramidal neurons were voltage-clamped at $-70 \mathrm{mV}$. The-evoked response has an initial synchronous component ( $\sim 50 \mathrm{~ms}$ after the stimulus artifact), which was excluded in the analysis. Isolated, asynchronous events that occurred from 50 to $500 \mathrm{~ms}$ after the stimulus were manually selected and analyzed using Minianalysis software (Synaptosoft). The detection threshold for events was set at $2 \times$ root mean square noise (usually $\sim 4-5 \mathrm{pA}$ ) and data were filtered with a low-pass filter at $1 \mathrm{kHz}$.

The frequency and amplitude of all EPSCs onto layer $2 / 3$ neurons were collected using $0.5 \mu \mathrm{M}$ tetrodotoxin (TTX; Sigma) in bath to block all firing activity in the slice. In this case, mEPSC amplitude measurements cannot be attributed to a single pathway, and represent the sum of diverse inputs to the cell.

Timed injection of NMDAR and mGluR5 antagonists. The NMDAR antagonist, CPP (10 mg/kg body weight) or the mGluR5 antagonist, MPEP $(10 \mathrm{mg} / \mathrm{kg})$ was injected intraperitoneally at different time points, and whole-cell recordings were performed on injected animals 24,48 , or $72 \mathrm{~h}$ after the onset of SWE. Injections were administered once, and animals were returned to their home cages until kill. In some SWEtreated animals, CPP was injected in combination with the removal of the remaining whisker, where CPP injection was performed immediately after the remaining whisker was removed.

Statistics. Approximately 100 randomly chosen Sr-EPSC events were selected and then grouped and averaged to obtain the average EPSC for each cell. Averaged Sr-EPSC traces for each experimental condition were obtained by first averaging responses from individual cells and then averaged these traces across all cells in the group. Mean Sr-EPSC amplitudes were averaged across cells for each condition. In general, control data were collected in interleaved experiments for each specific research question that was addressed.

Statistical significance was calculated between groups for each time point or drug manipulation. To accommodate random effects caused by animal-to-animal variability in our datasets, we used a generalized linear mixed model followed by simultaneous multiple pairwise comparisons. The $p$ values were adjusted for multiple comparisons described by Benjamini and Hochberg (1995) Cumulative distributions of EPSC event amplitude for different conditions were compared using KolmogorovSmirnov test. All statistical analyses were performed using the software program R. A $p<0.05$ was considered statistically significant, where ${ }^{\star} p \leq 0.05$ and ${ }^{* *} p \leq 0.01$, respectively.

\section{Results}

\section{Single-whisker and single-row experience both drive} synaptic potentiation

Previous experiments to examine whisker-induced synaptic strengthening have relied upon expression of the immediate early gene c-fos in the fosGFP transgenic mouse to identify the barrel column corresponding to the spared whisker (Barth et al., 2004). However, this method cannot reliably identify the spared barrel column at time intervals less than $\sim 18$ h of SWE due to poor resolution of the fosGFP signal in the spared versus the deprived barrel columns. To examine the early time course of plasticity, another form of selective whisker activation was adopted that preserved not one, but all whiskers in the D- row (SRE; Finnerty et al., 1999). This method allows unambiguous identification of the spared whisker representation in wild-type mice, in acute brain slices prepared to preserve the row identity (Fig. 1).

The effects of SRE on excitatory synaptic strength at individual layer 4-2/3 contacts can be assessed using a Sr-replaced ACSF solution to desynchronize neurotransmitter release, (Goda and Stevens, 1994; Xu-Friedman and Regehr, 1999). This method specifically evaluates postsynaptic changes in synaptic strength, and normalizes stimulation conditions across different brain 
A
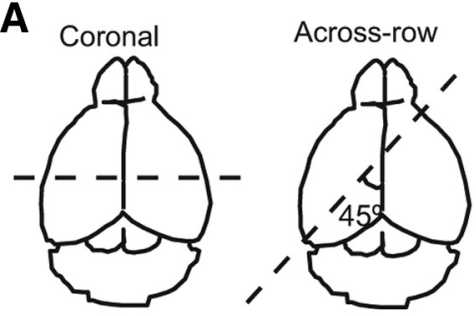

B
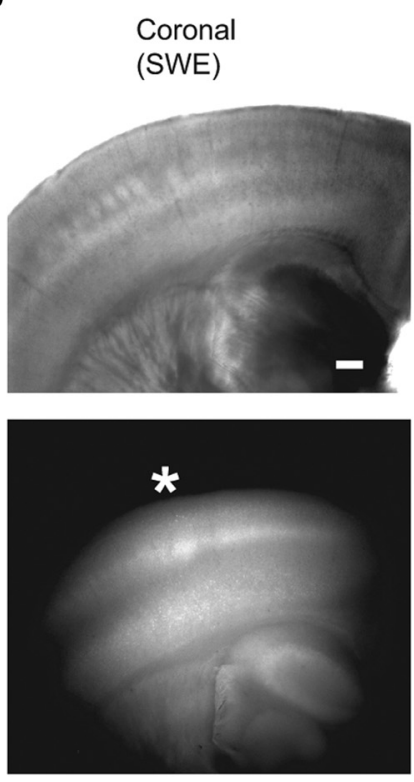

C $0 \mathrm{hr}$

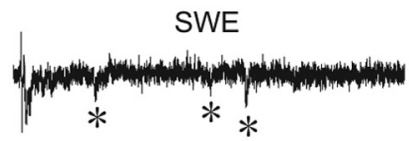

$24 \mathrm{hr}$.
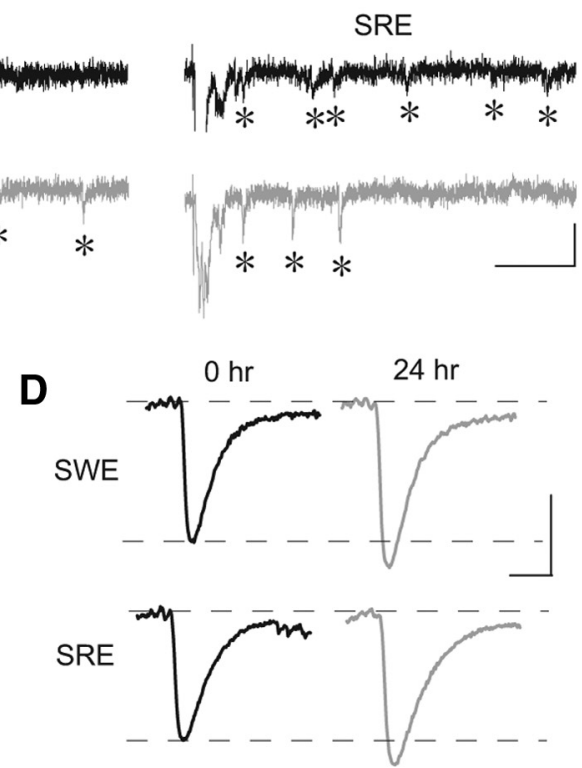

E

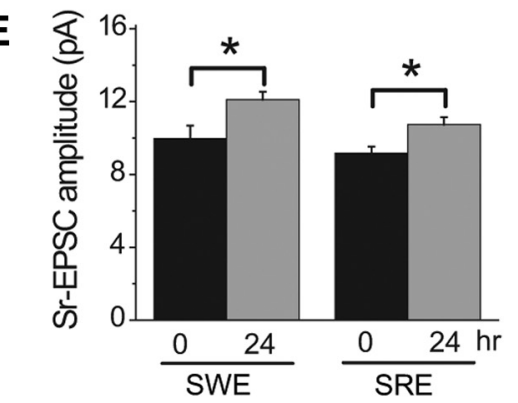

Figure 1. SRE is similar to SWE. $\boldsymbol{A}$, Schematic of two different slicing procedures, coronal versus parasagittal ("across-row"). $\boldsymbol{B}$, Images of slices that contain layer 4 barrels using coronal and across-row slice preparations. Top, Bright-field images. Scale bar, $300 \mu \mathrm{m}$. Bottom, Fluorescent image of a coronal slice that contains the spared D1 barrel $\left({ }^{*}\right)$ from a fosGFP animal after $24 \mathrm{~h}$ SWE. D, dorsal; $M$, medial. C, Example traces of layer 4-evoked Sr-EPSCs in layer $2 / 3$ pyramidal cells recorded from animals that underwent 0 and $24 \mathrm{~h}$ of SWE versus SRE, in coronal and parasagittal slices, respectively. Calibration: 20 pA, 100 ms. *Individual Sr-EPSC events. D, Averaged traces of Sr-EPSCs from 0 and 24 h of SWE versus SRE. Black, 0 h; gray, 24 h. Calibration: 5 pA, 5 ms. E, Mean Sr-EPSC amplitudes recorded at 0 (SWE $n=9$ cells $/ 3$ animals, SRE $n=14$ cells $/ 4$ animals) and $24 \mathrm{~h}$ (SWE $n=15$ cells $/ 6$ animals, SRE $n=12$ cells $/ 3$ animals) of SWE and SRE.

slices and animals. In undeprived, control animals (0 h SRE), Sr-EPSC amplitudes were identical between SWE and SRE (Fig. $1 C-E$; SWE 0 h $9.9 \pm 0.80 \mathrm{pA}$, vs SRE 0 h $9.2 \pm 0.37 \mathrm{pA}, p=0.3$ ), suggesting that there is no bias in the population of synapses under investigation that might be introduced by different slicing protocols. The magnitude of synaptic potentiation after SWE was slightly lower than SRE (Fig. $1 E$; $\mathrm{SWE}_{24}$ h $11.9 \pm-0.43 \mathrm{pA}$, vs $\mathrm{SRE}_{24 \mathrm{~h}} 10.7 \pm 0.40 \mathrm{pA}, p=0.1$ ), likely because the retention of a single whisker more strongly drives plasticity in layer $4-2 / 3$ circuits. However, in both cases, a significant increase in mean SrEPSC amplitude was observed after $24 \mathrm{~h}$.

These initial comparisons suggest that SWE and SRE are similar in terms of their capacity to increase synaptic strength. Thus, SRE enables analysis of the early time points of sensory experience and can be used as a tool to study the progression of synaptic potentiation in vivo.

\section{The initiation phase of experience-dependent plasticity}

Given that there was an overall smaller increase in synaptic strength after SRE compared with SWE at $24 \mathrm{~h}$, it was unclear whether smaller increments of change could be resolved using this assay. However, this concern was unwarranted, as shorter intervals of SRE were in fact more effective at driving robust increase in Sr-EPSC amplitude.
Compared with undeprived, control animals, mean Sr-EPSC amplitude at 6 and $12 \mathrm{~h}$ showed a progressive, linear increase (Fig. $2 \mathrm{~B}, \mathrm{C} ; 0 \mathrm{~h} 9.2 \pm 0.37 \mathrm{pA} ; 6 \mathrm{~h} 11.4 \pm 0.55 \mathrm{pA} ; 12 \mathrm{~h} 13.1 \pm 0.40 \mathrm{pA}$, 0 vs $6 \mathrm{~h}, p=0.03$; 6 vs $12 \mathrm{~h}, p=0.08 ; 0$ vs $12 \mathrm{~h}, p<0.0001$ ). Overall, Sr-EPSC amplitude increased by $\sim 40 \%$ from 0 to $12 \mathrm{~h}$ and the rate of synaptic strengthening was relatively constant between 0 and $6 \mathrm{~h}$ and $6-12 \mathrm{~h}(\sim 0.3 \mathrm{pA} / \mathrm{h})$. Although individual events varied over a large amplitude range (3.2-48.7 pA), a cumulative distribution of event amplitudes shows a progressive rightward shift from 0 to $6 \mathrm{~h}$ and from 6 to $12 \mathrm{~h}$ (Fig. $2 D ; 0$ vs $6 \mathrm{~h}$, $p<0.001 ; 6$ vs $12 \mathrm{~h}, p<0.001)$. These data show that during the first $12 \mathrm{~h}$ of SRE, excitatory synaptic strength can be profoundly enhanced, and that the magnitude of potentiation has been underestimated by previous analyses that focused on later time points.

\section{The labile phase: further experience reduces prior gains in synaptic strength}

The fact that Sr-EPSC amplitudes were significantly larger at $12 \mathrm{~h}$ than at $24 \mathrm{~h}$ suggested that further experience might not just be ineffective at inducing further potentiation, but might be actively suppressing existing gains. Sr-EPSCs recorded at $24 \mathrm{~h}$ of SRE were $\sim 2 \mathrm{pA}$ smaller compared with the peak measured at $12 \mathrm{~h}$ (Fig. $3 A, B ; 18 \mathrm{~h} 12.4 \pm 0.56 \mathrm{pA}$ and $24 \mathrm{~h} 10.7 \pm 0.35 \mathrm{pA}, 12 \mathrm{vs} 18 \mathrm{~h}, \mathrm{p}=$ 
$0.5,18$ vs $24 \mathrm{~h} p=0.09,12$ vs $24 \mathrm{~h}, p=$ $0.03)$. This decrease in synaptic strength was also evident from an overall leftward shift in the cumulative distribution (Fig. $3 C$; 12 vs $18 \mathrm{~h}, p<0.001 ; 18$ vs $24 \mathrm{~h}, p<$ 0.001 ), where all events appeared to be reduced, compared with an increase in the frequency of very small events that might drive down the mean amplitude. The calculated rate of synaptic weakening between 12 and $24 \mathrm{~h}$ of SRE was $\sim 0.2 \mathrm{pA} / \mathrm{h}$, slightly smaller than that of synaptic strengthening between 0 and $12 \mathrm{~h}$, resulting in a net gain in input amplitude at $24 \mathrm{~h}$.

Since the spared barrel could be identified in SWE-treated fosGFP mice at $18 \mathrm{~h}$ after the SWE onset, the effects of SRE and SWE could be directly compared at this time point. Consistent with the results from SRE-treated animals at $18 \mathrm{~h}$, mean Sr-EPSC amplitude was higher at $18 \mathrm{~h}$ compared with $24 \mathrm{~h}$ in SWE-treated animals (Fig. 3D). There was no significant difference in the fold change in synaptic strength at $18 \mathrm{~h}$ or $24 \mathrm{~h}$ between the two conditions (Fig. 3D). Thus, both whiskerdeprivation paradigms showed an early potentiation phase where synaptic strength is significantly enhanced and a labile phase, where synaptic strength is then reduced. These data suggest there is a transition in how layer $4-2 / 3$ synapses respond to selective whisker activation, where long periods of selective whisker stimulation activity do not progressively increase synaptic strength.

\section{Synaptic weakening does not occur at all synapses across the cell}

Synaptic scaling, or the reduction of synaptic weights based upon increased network activity, has been observed in neocortical neurons in young postnatal animals (Turrigiano et al., 1998). Synaptic scaling is a slow process that occurs across all excitatory inputs to the cell, requires NMDAR-activation, and typically requires several days to become manifest (Turrigiano et al., 1998; for review, see Sutton et al., 2004). It is conceivable that the synaptic weakening observed during the labile phase might be concurrent with a delayed-onset cellwide synaptic rescaling. Thus, the initiation phase would represent an input-specific synaptic strengthening, and the subsequent labile phase would be a global rescaling of synaptic weights to maintain total input strength over some target range.

To examine the mean amplitude for all excitatory inputs onto the cell, we measured mEPSCs for layer $2 / 3$ neurons in the presence of the Na-channel blocker, TTX (Fig. 4A). Mean mEPSC amplitude for layer $2 / 3$ neurons from control undeprived ani-

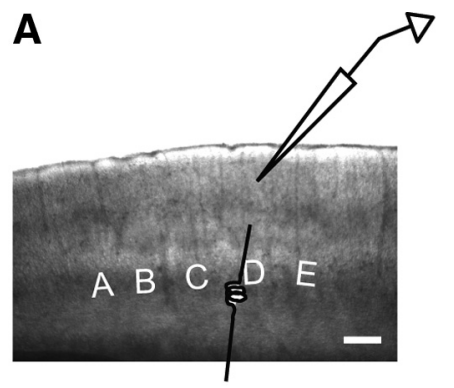

B
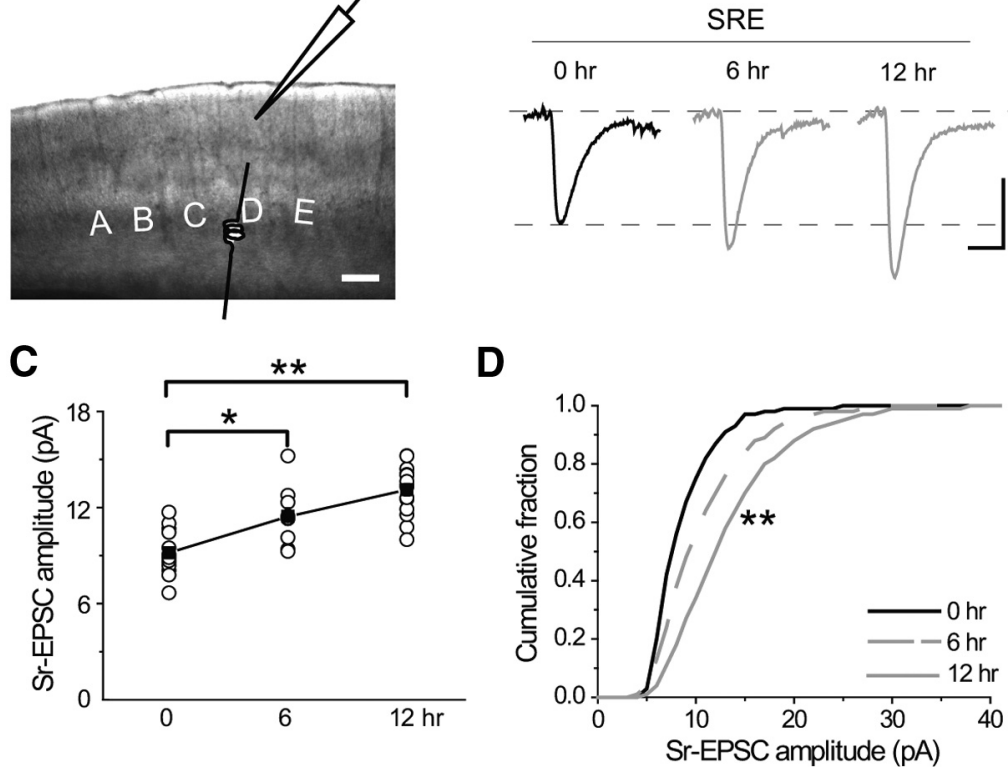

Figure 2. The initiation phase: synaptic potentiation at layer $4-2 / 3$ synapses. $\boldsymbol{A}$, Schematic of a parasagittal slice containing A-E barrels with electrode configurations. Scale bar, $300 \mu \mathrm{m}$. $\boldsymbol{B}$, Averaged Sr-EPSC from animals after 0, 6, and $12 \mathrm{~h}$ of SRE. Calibration: 5 pA, 5 ms. C, Scatter plot of mean Sr-EPSC amplitude recorded at 0 ( $n=14$ cells $/ 4$ animals), 6 ( $n=10$ cells $/ 3$ animals), and $12 \mathrm{~h}$ ( $n=15$ cells $/ 3$ animals) of SRE. D. Cumulative histograms of Sr-EPSC amplitude from animals after 0,6 , and $12 \mathrm{~h}$ of SRE. ${ }^{* *} p<0.001$ between 0 and $6 \mathrm{~h}$ and between 6 and $12 \mathrm{~h}$.
A
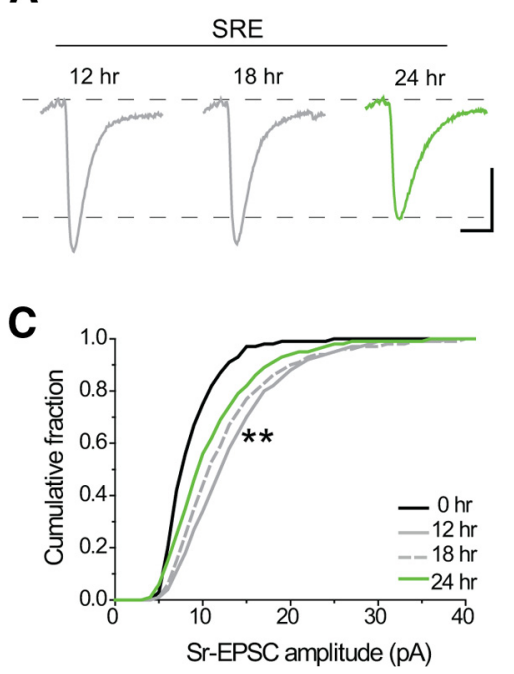

B

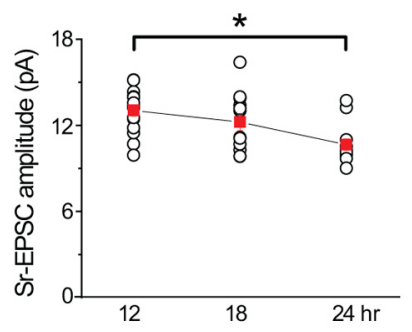

D

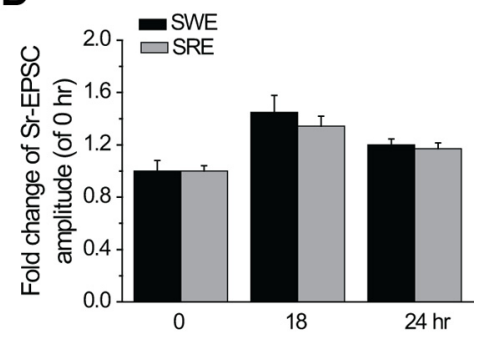

Figure 3. The labile phase: reduction in synaptic strength at layer $4-2 / 3$ synapses. $\boldsymbol{A}$, Averaged Sr-EPSC recorded from animals after 12, 18, and $24 \mathrm{~h}$ of SRE. Calibration: 5 pA, 5 ms. B, Scatter plot of mean Sr-EPSC amplitude recorded at 12, 18 ( $n=13$ cells/3 animals), and $24 \mathrm{~h}$ ( $n=14$ cells/3 animals) of SRE. C, Cumulative histograms of Sr-EPSC amplitude recorded at $0,12,18$, and $24 \mathrm{~h}$ of SRE. ${ }^{* *} p<0.001$ between 12 and $18 \mathrm{~h}$ and between 18 and $24 \mathrm{~h}$. D, Comparison of mean Sr-EPSC amplitude between SWE (black) and SRE (gray) normalized to the average $0 \mathrm{~h}$ values for SWE and SRE.

mals was $10.5 \pm 0.5 \mathrm{pA}$ (Fig. $4 B, C, E$; age range P13-P14). This value was compared with mean mEPSC amplitude during the middle of the labile phase, at $18 \mathrm{~h}$ of SRE, as we reasoned that cell-wide synaptic scaling might be most pronounced here. However, mean mEPSC values were unaltered at this time point (Fig. $4 B, C, E ; 10.3 \pm 0.4 \mathrm{pA}$; age range $\mathrm{P} 13$; vs control $10.5 \pm 0.5 \mathrm{pA}$, $p=0.8$ ). The cumulative distribution of event amplitude for these two data points was overlapping (Fig. $4 D$ ); however, there was a statistically significant difference $(p=0.04)$. This should be 
A

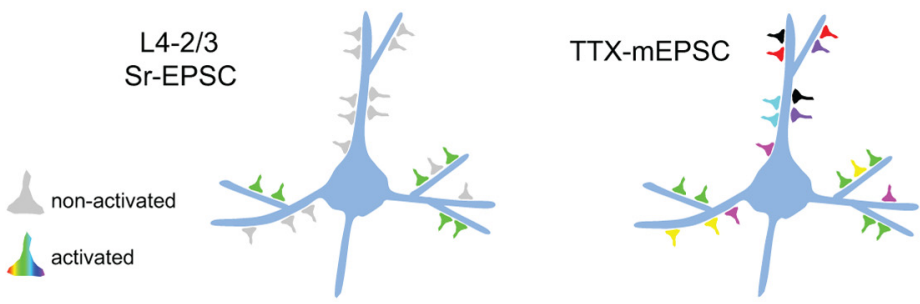

B TTX-mEPSCs

$\mathrm{Ct|}$
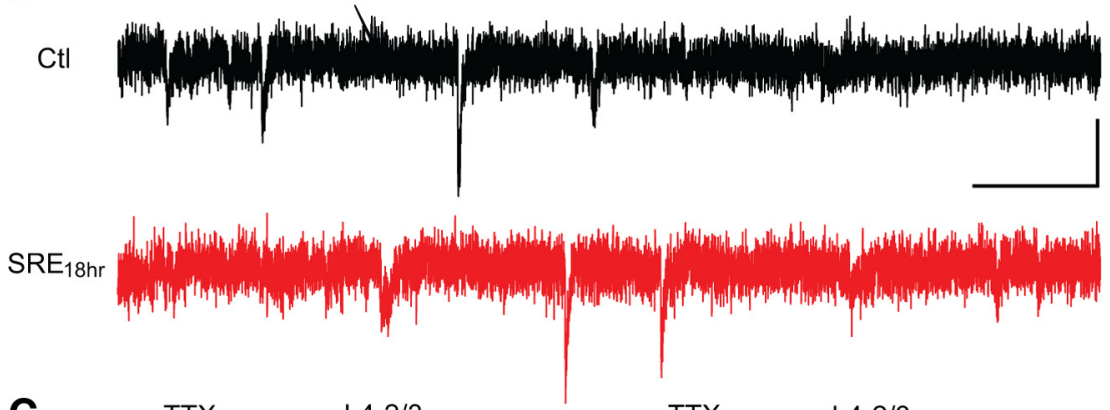

C
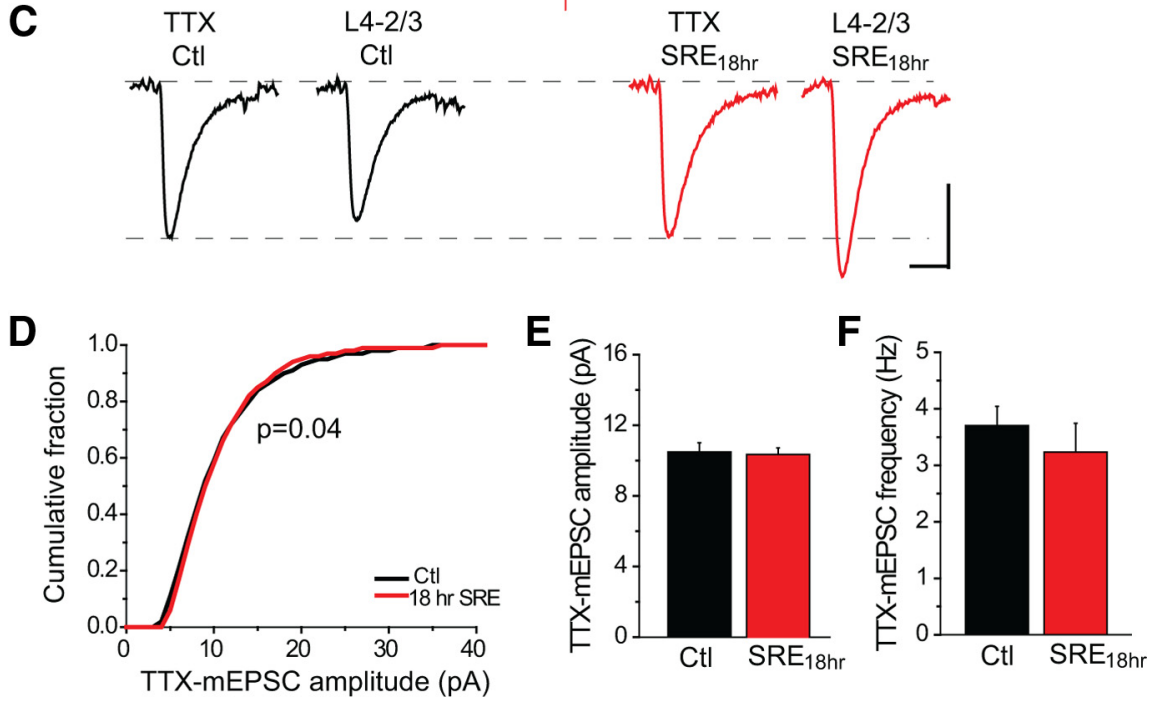

Figure 4. Synaptic lability at recently potentiated synapses is not associated with cell-wide homeostatic scaling. $\boldsymbol{A}$, Depiction of layer 4-2/3 synapses (green, left) during recording of layer 4-2/3 Sr-EPSCs and of all excitatory inputs (all colors, right) onto a layer $2 / 3$ pyramidal neuron during recording of TTX-mEPSCs. $\boldsymbol{B}$, Example mEPSCs measured in the presence of TTX (TTX-mEPSCs) from control and SRE ${ }_{18}$. Calibration: 10 pA, $200 \mathrm{~ms}$. C, Averaged TTX-mEPSCs compared with Sr-EPSCs at layer 4 -2/3 synapses for control and $18 \mathrm{~h}$ SRE-treated animals. D, Cumulative histograms of TTX-mEPSC amplitudes from control and $18 \mathrm{~h}$ SR-treated animals. $\boldsymbol{E}$, Mean TTX-mEPSC amplitude from control (Ctl; $n=12$ cells $/ 3$ animals) and $18 \mathrm{~h} \mathrm{SRE-treated} \mathrm{animals}(n=9$ cells $/ 3$ animals). $\boldsymbol{F}$, Mean TTX-mEPS( frequency from control and $18 \mathrm{~h}$ SRE-treated animals.

compared with the shift in Sr-EPSC amplitude event distribution at the layer $4-2 / 3$ pathway for these two time points (Fig. $3 C, 0 \mathrm{~h}$ vs $18 \mathrm{~h}, p<0.001)$. The frequency of mEPSCs between the control and $18 \mathrm{~h}$ SRE-treated animals was not significantly altered (Fig. $4 F, p=0.6$ ).

\section{In vivo blockade of NMDARs prevents synaptic weakening during the labile phase}

The identification of the specific time interval where gains in synaptic strength can be reduced or reversed facilitates identification of cellular mechanisms that underlie this form of synaptic metaplasticity. Previously we found that after the onset of whisker-driven potentiation, subsequent NMDAR activation triggers synaptic depression (Clem et al., 2008; Wen and Barth, 2012). Using the time intervals identified above, we investigated how systemic NMDAR blockade administered at different phases of plasticity could influence synaptic strength (Fig. 5). Intraperitoneal injections of the competitive NMDAR antagonist CPP were performed at various time points, and mean Sr-EPSC amplitude was calculated $24 \mathrm{~h}$ after whisker removal. Since all analysis was performed $24 \mathrm{~h}$ after whisker removal (when the spared barrel column was visible by fosGFP expression in an acute brain slice), the SWE preparation was used in these experiments.

Our previous work showed that injection of NMDAR-antagonist at the onset of SWE was sufficient to prevent experiencedependent synaptic strengthening, consistent with a requirement for NMDARs in long-term potentiation (LTP) at layer 4-2/3 synapses in vitro (Clem et al., 2008). Here we show that slightly later injections, $6 \mathrm{~h}$ after the onset of SWE, can also block increases in layer 4-2/3 Sr-EPSC amplitude (Fig. $5 A, D$; $\mathrm{SWE}_{6 \mathrm{~h} \mathrm{CPP}} 10.59 \pm 0.37$ $\mathrm{pA}$ vs control $9.87 \pm 0.24 \mathrm{pA}, p=0.4$ ), suggesting that NMDAR activation at this time is still required for synaptic strengthening at these synapses.

Mean Sr-EPSC amplitude in the spared barrel column peaks at $12 \mathrm{~h}$ after the onset of whisker manipulation, a putative transition point from the initiation to the labile phase. If NMDARs are required for synaptic weakening during the labile phase, blockade of these receptors could preserve these early gains in Sr-EPSC amplitude. This was indeed the case. CPP injection at $12 \mathrm{~h}$ after SWE onset prevented the expected decline in Sr-EPSC amplitude at $24 \mathrm{~h}$ (Fig. 5B,D; $\mathrm{SWE}_{12}$ h CPP $15.72 \pm 1.05 \mathrm{pA}$ vs $\mathrm{SWE}_{24 \mathrm{~h}}$ $\left.12.01^{12} \pm 0.63 \mathrm{pA}, p=0.002\right)$. These data indicate that that the transition from NMDAR potentiation to NMDAR depression has occurred by this time point, and suggest that blockade of NMDARs is sufficient for maintenance of the early gains in synaptic strength induced during the potentiation phase.

Sensory input and NMDAR-dependent depression during the labile phase

To test whether input-specific mechanisms that rely on ongoing whisker activity were important for synaptic lability, the remaining whisker was removed from SWE animals, $18 \mathrm{~h}$ after onset. The whisker was removed by plucking the hair from the follicle so that not even the whisker stub remained (Fig. 6A).

Interestingly, whisker removal during the labile phase appeared to enhance Sr-EPSC amplitudes compared with values obtained after $24 \mathrm{~h}$ of SWE (Fig. $6 B, C$; $\mathrm{SWE}_{24 \mathrm{~h}} 11.89 \pm 0.23 \mathrm{pA}$ vs $\left.\mathrm{SWE}_{18 \text { h pluck }} 13.86 \pm 0.65 \mathrm{pA}, p=0.3\right)$. Indeed, mean response amplitudes from animals plucked at $18 \mathrm{~h}$ and assessed at $24 \mathrm{~h}$ were identical to values following $18 \mathrm{~h}$ of SWE (Fig. 6B, C; $\mathrm{SWE}_{18 \text { h pluck }} 13.86 \pm 0.65 \mathrm{pA}$ vs $\mathrm{SWE}_{18 \mathrm{~h}} 13.92 \pm 1.38 \mathrm{pA}, p=$ 
0.8 ), suggesting that prior gains in synaptic strength were fully maintained. Consistent with this, the cumulative distribution of SrEPSC amplitudes was right-shifted in plucked animals (Fig. $6 D ; p<0.0001$ ). These data show that ongoing sensorydriven activity may reverse prior plasticity during the labile phase. Notably, trimming the spared whisker (leaving a small stub on the snout) at the same $18 \mathrm{~h}$ time point did not preserve synaptic potentiation $\left(\mathrm{SWE}_{24 \mathrm{~h}} 11.55 \pm 0.50 \mathrm{pA}, n=18\right.$ cells vs $\mathrm{SWE}_{18}$ h Trim $11.9 \pm 0.69 \mathrm{pA}, n=$ 10 cells, $p=0.7)$. This result suggests that input via the whisker stub may be sufficient to engage synaptic depression during the labile phase.

The finding that whisker removal, like NMDAR blockade, is sufficient to maintain prior gains in Sr-EPSC suggested that these two manipulations might be related. To test this, we examined the effect of simultaneous whisker removal and NDMAR blockade (Fig. 6E). If whisker removal and in vivo NMDAR blockade acted through two different pathways to increase Sr-EPSC amplitude, we might observe an additive effect of these two manipulations together. Alternatively, if these mechanisms were part of the same pathway, there should be no further increase.

At $18 \mathrm{~h}$ after SWE onset, animals were injected with CPP and the remaining spared whisker was removed $\left(\mathrm{SWE}_{18} \mathrm{~h}\right.$ pluck $+\mathrm{CPP})$. Sr-EPSC amplitudes at layer $4-2 / 3$ inputs were then evaluated $6 \mathrm{~h}$ later (Fig. $6 E$ ). CPP injection had no greater effect when combined with whisker removal at $18 \mathrm{~h}$ (Fig. 6F, G; $\mathrm{SWE}_{18 \text { h pluck }} 13.86 \pm 0.65 \mathrm{pA}$ vs $\mathrm{SWE}_{18 \mathrm{~h} \mathrm{CPP}} 13.35 \pm 0.47 \mathrm{pA}$ vs $\mathrm{SWE}_{18 \text { h pluck }+\mathrm{CPP}} 13.19 \pm 0.74 \mathrm{pA}, p=0.9$ for all comparisons). The cumulative distribution of Sr-EPSC amplitudes was also not different between the three cases (Fig. $6 H$ ). Thus, we propose that loss of sensory input during the labile phase can act to maintain prior gains in synaptic strength by circumventing NMDARdependent depression.

\section{The stabilization phase}

Given the opposition between NMDAR-dependent potentiation and NMDAR-dependent depression on EPSC amplitude after the onset of synaptic strengthening in vivo, what happens during longer periods of selective whisker experience? Sr-EPSC amplitudes at layer $4-2 / 3$ synapses in the spared whisker barrel column remain elevated for days after the onset of SWE (Fig. 7; SWE $48 \mathrm{~h}$ $11.30 \pm 0.56 \mathrm{pA}$ vs $\mathrm{SWE}_{72 \mathrm{~h}} 11.13 \pm 0.39 \mathrm{pA}$, compared with $\mathrm{SWE}_{24} 11.75 \pm 0.44 \mathrm{pA}$; Fig. 1). These data indicate that NMDAR-dependent depression is not sufficient to eliminate experience-dependent synaptic potentiation over these longer time periods. This might be the case because the labile phase is transient, or because the rate of depression progressively slows.

To examine whether NMDAR-dependent synaptic weakening was still active at these later time points, CPP was injected at $36 \mathrm{~h}$ after SWE onset, and Sr-EPSCs were evaluated at $48 \mathrm{~h}$ (Fig. $7 A$ ). If the labile phase is prolonged, we expected that this $12 \mathrm{~h}$ treatment would result in larger Sr-EPSCs, as was observed with earlier injections (Fig. 5). However, we found that later NMDAR blockade had no effect on mean Sr-EPSC amplitude (Fig. 7 A, $C$; $\mathrm{SWE}_{48 \mathrm{~h}} 11.30 \pm 0.56 \mathrm{pA}$ vs $\left.\mathrm{SWE}_{36 \mathrm{~h} \mathrm{CPP}} 11.14 \pm 0.73 \mathrm{pA}, p=0.8\right)$ Later injections of CPP, $60 \mathrm{~h}$ after SWE onset, also showed no effect at $72 \mathrm{~h}\left(\right.$ Fig. $7 \mathrm{~B}, \mathrm{C}$; $\mathrm{SWE}_{72 \mathrm{~h}} 11.13 \pm 0.39 \mathrm{pA}$ vs $\mathrm{SWE}_{60 \mathrm{~h} \mathrm{CPP}}$ $11.85 \pm 0.50 \mathrm{pA}, p=0.8)$. Unlike NMDAR blockade at $12-18 \mathrm{~h}$ following SWE onset, later blockade has no effect on excitatory synaptic strength. Thus, NMDAR activation does not reduce experience-dependent synaptic strengthening in the spared barrel column after the first $36 \mathrm{~h}$ of selective whisker experience, where responses appear to be stabilized.

\section{mGluR5 activity is required for stabilization}

Previous work suggested that group I mGluRs might be required to maintain synaptic strength during the period we have now identified as the labile phase (Clem et al., 2008). Here we identify that mGluR5 is the specific group I mGluR required, using the mGluR5-specific antagonist MPEP. Intraperitoneal injection of MPEP during the labile phase (18 h post-SWE onset) was sufficient to eliminate whisker-induced potentiation, reducing $\mathrm{Sr}$ EPSC amplitudes back to baseline levels (Fig. $8 A, B$; SWE $_{18 \mathrm{~h} \text { MPEP }}$ $9.94 \pm 0.65 \mathrm{pA}$ vs $\left.\mathrm{SWE}_{24 \mathrm{~h}} 12.72 \pm 0.45 \mathrm{pA}, p=0.0002\right)$. These results extend findings reported earlier for the nonspecific group I antagonist, AIDA (Clem et al., 2008), identifying mGluR5 as the critical receptor subtype involved in this process.

Is mGluR5 activity required to offset the depressing function of NMDAR activation only during the labile phase? To answer this question, animals were injected with MPEP $36 \mathrm{~h}$ after SWE onset and assessed at $48 \mathrm{~h}$. This treatment was sufficient to 
A

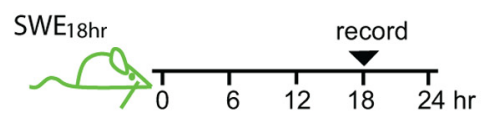

$\mathrm{SWE}_{24 \mathrm{hr}}$
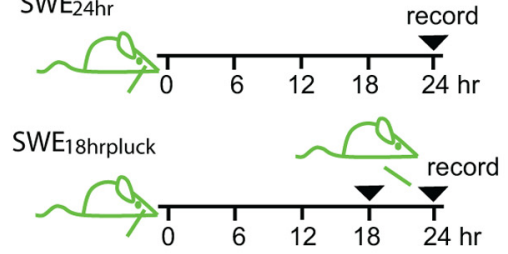

C

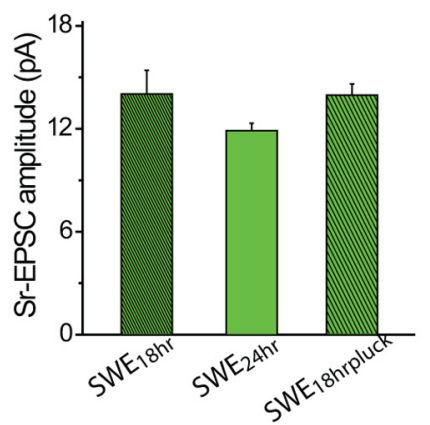

E
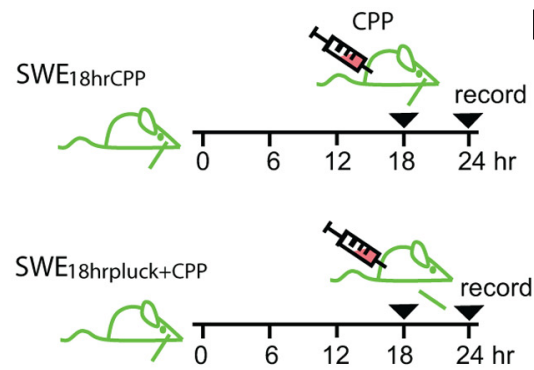

$\mathbf{F}$

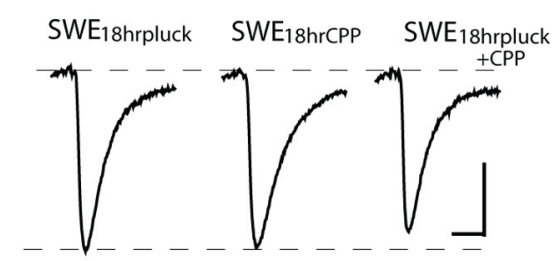

G

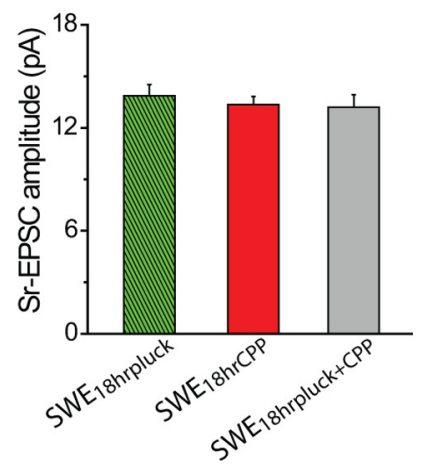

H

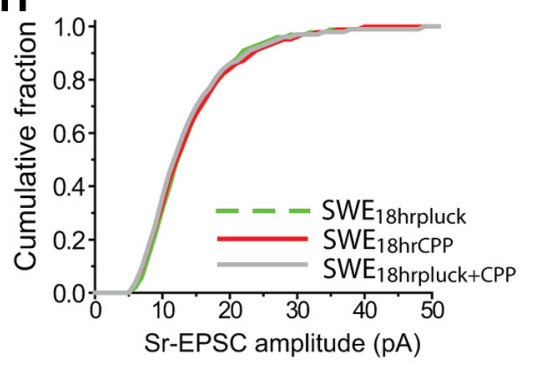

Figure 6. Sensory input and NMDAR-dependent synaptic depression during the labile phase. $A$, Experimental design for spared whisker removal and recording times. $\boldsymbol{B}$, Averaged Sr-EPSC for SWE $\mathrm{S}_{18 \mathrm{~h}}, \mathrm{SWE}_{24 \mathrm{~h}}$, and SWE 18 h pluck. $\boldsymbol{C}$, Mean Sr-EPSC amplitude recorded from SWE-treated animals at $18 \mathrm{~h}$ (SWE $18, h^{\prime} n=8$ cells/4 animals) and $24 \mathrm{~h}$ (SWE $24, h^{\prime} n=15$ cells $/ 6$ animals), and from SWE-treated animals with the spared whisker removed at $18 \mathrm{~h}$ and assessed at $24 \mathrm{~h}\left(\mathrm{SWE}_{18} \mathrm{~h}\right.$ pluck',$n=7 \mathrm{cells} / 3$ animals). $\boldsymbol{D}$, Cumulative histograms of $\mathrm{Sr}$-EPSC amplitudes for SWE $24 \mathrm{~h}$ and $\mathrm{SWE}_{18 \mathrm{~h} \text { pluck }}{ }^{* *} p<0.001$. E, Experimental design for SWE-treated animals with CPP injection at $18 \mathrm{~h}\left(\mathrm{SWE}_{18 \mathrm{~h} C P P}, n=21\right.$ cells/8 animals) and SWE-treated animals with CPP injection in combination

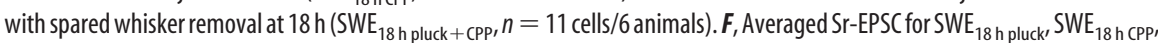
and SWE $_{18 \text { h pluck + CPP. }} \mathbf{G}$, Mean Sr-EPSC amplitude. $\boldsymbol{H}$, Cumulative histograms of Sr-EPSC amplitudes for the conditions shown in $\boldsymbol{G}$.

reduce Sr-EPSC amplitudes back to baseline levels (Fig. 8C,D; $\mathrm{SWE}_{36 \text { h MPEP }} 9.40 \pm 0.45 \mathrm{pA}$ vs $\mathrm{SWE}_{48}$ h $11.30 \pm 0.56 \mathrm{pA}$, $p=0.005 ; \mathrm{SWE}_{36 \mathrm{~h} \mathrm{MPEP}}$ vs control, $\left.p=0.9\right)$. Thus, the persistence of experience-dependent increases in layer $4-2 / 3$ excitatory synaptic strength requires continued activation of mGluR5 signaling pathways.
Time course of plasticity for layer $2 / 3-2 / 3$ synapses within the spared column

Do other neocortical synapses that are modified during SWE show the same phases of plasticity? Previous work has shown that SWE leads to the strengthening of layer $2 / 3-2 / 3$ synapses within the spared barrel column (Wen and Barth, 2011). To determine whether these synapses also showed three distinct phases of synaptic plasticity, we examined Sr-EPSC amplitude using a stimulating electrode positioned within the spared column (Fig. $9 A$ ), at a variety of time points following SRE.

Compared with layer 4-2/3 inputs, synaptic strength appeared to peak earlier for layer $2 / 3-2 / 3$ inputs, at $\sim 6 \mathrm{~h}$ following SRE onset (Fig. 9B, $C$; control $8.5 \pm 0.4$ pA vs $\mathrm{SRE}_{6 \mathrm{~h}} 10.9 \pm 0.5 \mathrm{pA}, p=0.0006$ ). By $12 \mathrm{~h}$, there was a small but significant dip in mean Sr-EPSC amplitude (9.4 \pm $0.4 \mathrm{pA}, p=0.02$ vs $6 \mathrm{~h}$ ). Synaptic strength appeared to stabilize between 18 and $24 \mathrm{~h}$ (Fig. 9B, C). These data suggest that other synapses within the spared barrel column might undergo a labile phase following potentiation, although the specific timing of these phases might differ.

\section{Discussion}

Here we use sensory experience to drive changes in neocortical circuits to investigate the timing and regulation of synaptic potentiation in vivo. The method used here specifically isolates changes in the postsynaptic response of pathway-specific inputs to layer $2 / 3$ pyramidal neurons. We find that synaptic strengthening at layer $4-2 / 3$ synapses within the spared barrel column(s) proceeds at a constant rate over the first $12 \mathrm{~h}$, resulting in a $\sim 40 \%$ increase in the amplitude of Sr-EPSCs compared with control, undeprived animals. This early peak is followed by a labile period lasting $<24 \mathrm{~h}$, where ongoing sensory input reduces EPSC amplitude in an NMDAR-dependent manner. Finally, experience-dependent changes are consolidated during the stabilization phase, where NMDAR-activation does not enhance or suppress further changes, but mGluR5 activation is required to maintain prior gains in synaptic strength.

Synaptic neurophysiologists have long postulated that prior synaptic strengthening can alter the requirements for future synaptic plasticity. The relationship between input activity and synaptic change has been formalized by Bienenstock, Cooper, and Munro (Bienenstock et al., 1982; Benuskov á et al., 1994; Abraham and Tate, 1997), and abundant experimental evidence has shown that excitatory synapses will depress with low-frequency stimulation and potentiate with 
A

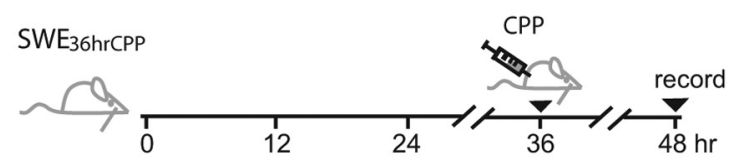

B

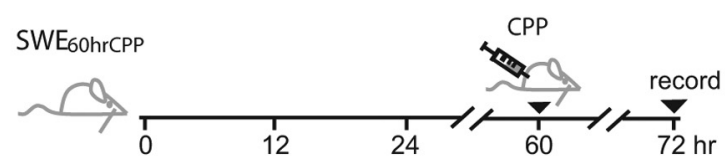

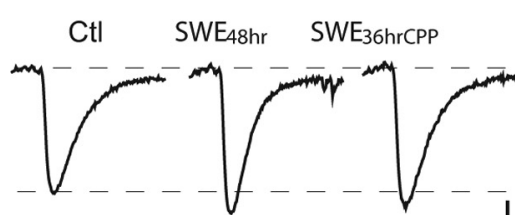

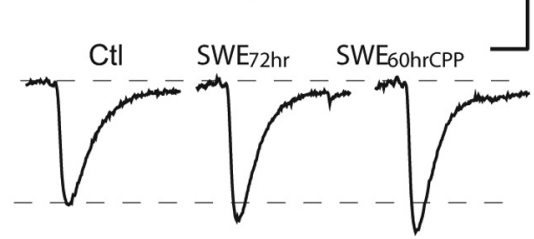

C

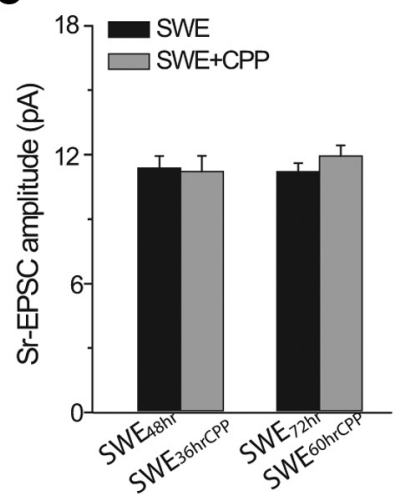

Figure 7. Synaptic strength is stabilized after the labile phase. A, NMDAR-blockade by CPP injection at $36 \mathrm{~h}$ does not change Sr-EPSC amplitude. Left, Experimental design for SWE-treated animals with (PP injection at $36 \mathrm{~h}$ and assessed at $48 \mathrm{~h}$ (SWE S6 $_{36}$ CP., P13-P14 animals). Right, Averaged traces. B, Injection of CPP at $60 \mathrm{~h}$ does not change Sr-EPSC amplitude. Left, Experimental design for SWE-treated animals with (PP injection at $60 \mathrm{~h}$ and assessed at $72 \mathrm{~h}\left(\mathrm{SWE}_{60} \mathrm{~h}\right.$ (PP). Right, Averaged traces. C, Summary of mean Sr-EPSC amplitude from SWE $48 \mathrm{~h}(n=11$ cells $/ 4$ animals), SWE $72 \mathrm{~h}$ $\left(n=14\right.$ cells $/ 5$ animals), and SWE-treated animals with CPP injection, $\operatorname{SWE}_{36 \mathrm{~h} \text { CPP }}(n=8$ cells $/ 2$ animals), and SWE $60 \mathrm{~h}$ cPP $(n=11$ cells $/ 4$ animals).

\section{A}

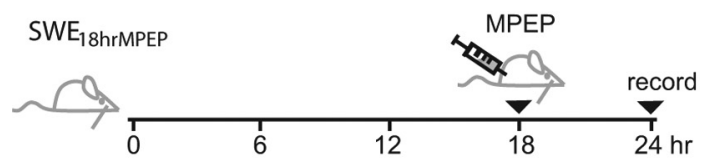

C

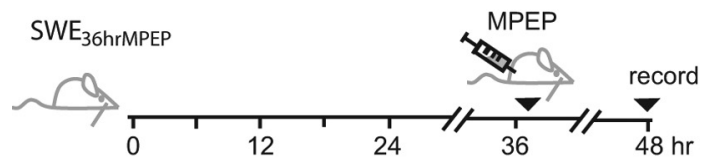

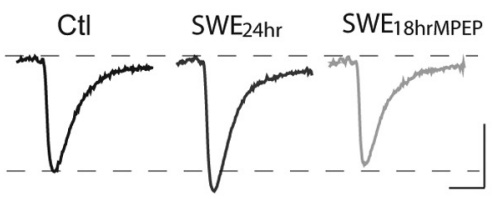

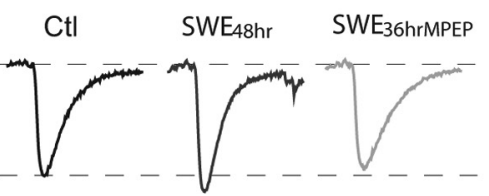

B

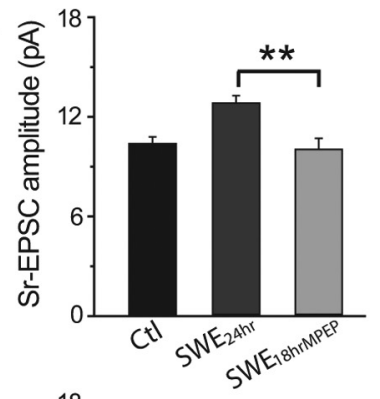

D

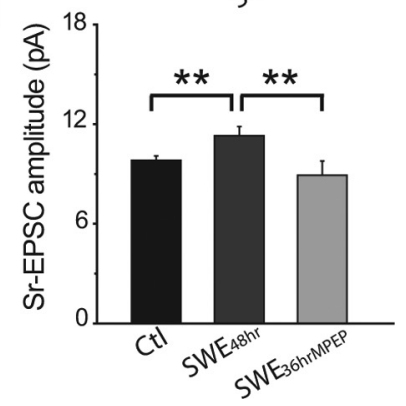

Figure 8. mGluR5 activity is required to maintain synaptic strength. $A, M P E P$ abolishes SWE-induced potentiation when injected at $18 \mathrm{~h}$. Left, Experimental design for SWE-treated animals with MPEP injection at $18 \mathrm{~h}$, assessed at $24 \mathrm{~h}$ (SWE $18 \mathrm{~h}$ MPEP). Right, Averaged traces. Black, control (P13); dark gray, SWE $24 \mathrm{~h}$ (P13); light gray, SWE $18 \mathrm{~h} \mathrm{MPEP}$ (P13). Calibration: 5 pA, 5 ms. B, Summary of Sr-EPSC amplitudes from control ( $n=10$ cells/4 animals), SWE $24 \mathrm{~h}(n=11$ cells $/ 3$ animals), and SWE $18 \mathrm{~h} \mathrm{MPEP}$ ( $n=12$ cells $/ 3$ animals). C, MPEP abolishes synaptic potentiation when injected at $36 \mathrm{~h}$. Left, Experimental design for SWE-treated animals with MPEP injection at $36 \mathrm{~h}$ and assessed at $48 \mathrm{~h}$ (SWE $36 \mathrm{~h} \mathrm{MPEP}$ ). Right; Average traces. Black, control (P13); dark gray, SWE ${ }_{48} \mathrm{~h}(\mathrm{P} 13-\mathrm{P} 14)$; light gray, SWE $36 \mathrm{~h} \mathrm{MPEP}$ (P13). D, Summary of mean Sr-EPSC amplitude from control ( $n=10$ cells/4 animals), SWE $48 \mathrm{~h}$ ( $n=11$ cells $/ 4$ animals), and SWE $36 \mathrm{~h} \mathrm{MPEP}$ ( $n=11$ cells/3 animals).

high-frequency stimulation (Dudek and Bear, 1992; Kirkwood et al., 1993; Malenka and Bear, 2004). Furthermore, the relationship between stimulation frequency and synaptic changes can be left shifted by prior experience (Bear, 1995; Philpot et al., 2003, 2007). Our data fit nicely into this general model, where a rightward shift of the frequency-response function would lead to depression at recently strengthened layer $4-2 / 3$ synapses. However, our data indicate that this shift may be a temporary phenomenon, identifying a short temporal window of synaptic lability after potentiation has occurred.

The reversibility of experience-induced increase in synaptic strength has parallels in vitro, where subsequent activity following an initial LTP induction can degrade synaptic strengthening, a process that has been referred to as depotentiation (Barrionuevo et al., 1980; Fujii et al., 1991; Bashir and Collingridge, 1994). We have also observed an NMDAR-dependent variant of this process at SWE-potentiated layer 4-2/3 synapses in vitro (Wen and Barth, 2012). This process of active decay has also been observed in vivo (Xu et al., 1998; Villarreal et al., 2002; Zhou et al., 2003; Whitlock et al., 2006; Qi et al., 2013). Our analysis of the time course of plasticity at layer $2 / 3-2 / 3$ suggests that a similar phenomenon might also be occurring at these inputs, albeit with slightly different timing. Thus, the phases we identify here may be observed at many different types of synapses across the nervous system.

\section{Homeostatic versus pathway-specific changes}

Is synaptic downscaling, as a response to increased firing activity in the spared barrel columns, sufficient to account for the labile phase? Prior studies have shown that increasing activity can downscale global EPSC amplitudes in neocortical neurons (Turrigiano et al., 1998), and that this homeostatic process re- 

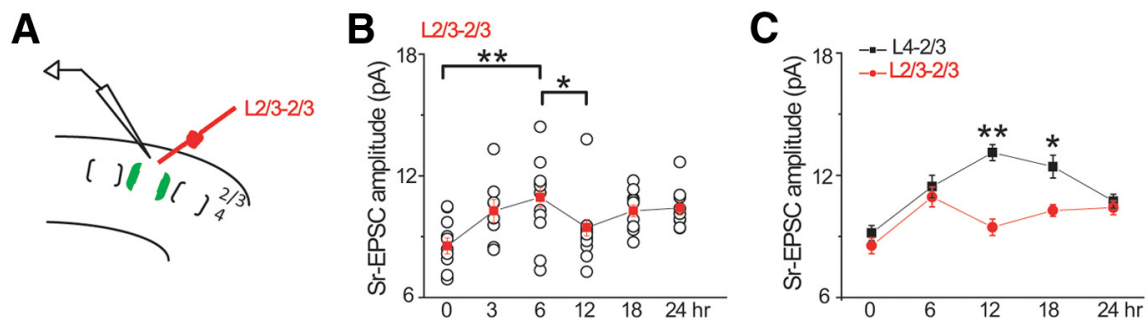

Figure 9. Layer $2 / 3-2 / 3$ synapses in the spared column show similar phases of plasticity, with earlier timing. $A$, Schematic of electrode positions for stimulation of layer 2/3-2/3 pathway within the spared column. $\boldsymbol{B}$, Summary of Sr-EPSC amplitudes recorded in control ( $n=11$ cells $/ 3$ animals), SRE $E_{3 \mathrm{~h}}\left(n=8\right.$ cells $/ 2$ animals), $\operatorname{SRE}_{6 \mathrm{~h}}\left(n=14\right.$ cells $/ 3$ animals), $\operatorname{SRE}_{12 \mathrm{~h}}(n=15$ cells $/ 3$ animals), $\operatorname{SRE}_{18 \mathrm{~h}}$ ( $n=11$ cells $/ 3$ animals), and SRE ${ }_{24 \mathrm{~h}}$ ( $n=9$ cells $/ 3$ animals). C, Comparison of the time courses of Sr-EPSC amplitudes recorded at layer 4-2/3 (black; replotted from Fig. $2+3$ ) and layer 2/3-2/3 synapses (red). Layer 2/3-2/3 synapses show a shorter potentiation phase and an earlier labile phase compared with layer $4-2 / 3$ synapses. Asterisks indicate significance for comparison of Sr-EPSC amplitude at layer $4-2 / 3$ inputs versus layer $2 / 3-2 / 3$ input at the indicated time points. All animals were evaluated at age P13-P14.

quires several days to occur. Although mean mEPSC amplitudes were unchanged between control animals and the middle of the labile phase, our data indicate that there may be some small degree of downscaling, specifically of larger EPSCs, at this time (i.e., Fig. 4D). If a cell-wide synaptic downscaling was the best explanation for the decrease in excitatory synaptic strength, it should be manifested similarly for all inputs to the cell as for layer $4-2 / 3$ synapses. This was not the case. We note that previous manipulations to examine homeostatic changes in synaptic strength have required profound modulation of neural activity, such as total blockade of fast GABAergic synaptic transmission (O'Brien et al., 1998; Turrigiano et al., 1998) or complete sensory deprivation (Desai et al., 2002). The lack of strong evidence for synaptic scaling may be related to the relatively modest change in activity introduced by SWE or SRE.

Can synaptic homeostasis occur in a pathway-specific manner? Previous studies suggest that this can occur, although the timescale of this response may be quite different (Hou et al., 2011). Indeed, we suggest that this synapse-specific process may be akin to the labile phase identified in the current study. We propose that cell-wide changes in input strength should be considered homeostatic, as the cell globally responds to changes in firing activity, and pathway-specific changes may be part of a mechanistically distinct process. Future experiments will be required to differentiate these phenomena.

\section{Changes in NMDAR properties during experience-dependent plasticity}

Our experiments indicate that there is a distinct transition in NMDARs between the initiation and the labile phases. How is NMDAR function altered to reverse the sign of plasticity at layer $4-2 / 3$ synapses? NMDAR activation can strongly influence network activity and change-evoked firing rates, indirectly influencing plasticity induction. However, in vivo recordings from anesthetized mice indicate that mean firing rates of layer 4 neurons are not altered $24 \mathrm{~h}$ after SWE onset (Benedetti et al., 2009). Our previous experiments (Clem et al., 2008) show that even when presynaptic activity is controlled and postsynaptic firing is blocked, the sign of plasticity is still inverted in acute brain slices from SWE-treated animals (i.e., LTP-inducing stimuli trigger long-term depression after $24 \mathrm{~h} \mathrm{SWE}$ ), and that this phenomenon depends upon NMDAR activation and an increase in postsynaptic $\mathrm{Ca}^{2+}$. In light of this, we propose that the changes in NMDAR function are likely to occur at synapses, influencing signaling pathways locally.
Both presynaptic and postsynaptic NMDARs have been described at layer 4-2/3 synapses (Brasier and Feldman, 2008; Rodríguez-Moreno and Paulsen, 2008), and our data do not enable us to assess the relative contribution of these two different NMDAR pools. However, we note that our measurements of synaptic strength exclusively measure postsynaptic response, and the overall outcome of this change in NMDAR function during SWE is clearly manifested as a change in postsynaptic AMPAR-mediated currents (Clem and Barth, 2006). It will be of interest to examine experience-dependent changes in presynaptic properties at layer $4-2 / 3$ synapses. Identification of these distinct phases of plasticity will facilitate more detailed investigations into how NMDAR function can be altered by prior synaptic strengthening.

\section{Enhancing plasticity through pharmacological and behavioral interventions}

Data presented here suggest interventions by which synaptic strengthening, or learning, might be enhanced. It is difficult to identify the exact timing of glutamate receptor blockade required for effects described here (because the specific bioavailability of the injected antagonist was not determined), although prior work indicates that both MPEP and CPP can antagonize mGluR5 and NMDARs for hours after injection, with the mGluR-antagonist effects of MPEP lasting at least $1-2 \mathrm{~h}$ and the NMDAR-antagonist effects of CPP lasting at least $3 \mathrm{~h}$ and up to $24 \mathrm{~h}$ after injection (Villarreal et al., 2002; Anderson et al., 2003). In almost all cases, we found a positive effect of antagonist injection, indicating that at aiven time range the compound was sufficient to disrupt plasticity processes. It will be of interest to determine the precise time of transition in glutamate receptor function during these three phases of plasticity; this may be facilitated by experiments in acute brain slices (Clem et al., 2008).

We found that eliminating input activity (by removal of the spared whisker) phenocopies pharmacological inactivation of NMDARs. Altering input activity is a more accessible approach to enhance stimulus encoding in vivo, compared with systemic administration of NMDAR antagonists, which would have many side effects. In addition, these findings suggest strategies for memory weakening, by timing input reactivation during the labile phase. Interestingly, this behavioral approach has been used to reduce fear memories in rodents (Myers et al., 2006; Monfils et al., 2009) and may be useful for treating post-traumatic stress disorder in humans (Mahan and Ressler, 2012).

\section{Parallels to human studies}

Our identification of the initiation, labile, and stabilization phases in the plasticity of neocortical synapses has remarkable parallels in human memory studies. Many forms of memory exhibit an encoding, or initiation phase, followed by a labile phase where the "memory trace" is susceptible to interference by presentation of distractor stimuli or of pharmacological compounds that interfere with gene transcription and translation (for review, see Nader et al., 2000). In addition, consolidation, the postacquisition stabilization of memory, has been well described in many experimental paradigms (Dudai, 2004). 
Whisker-induced plasticity in the developing somatosensory cortex may appear distantly related to memory as applied to other human and animal studies. However, it is striking that the distinct phases identified in the current study, which focused on a single class of neocortical synapses, show such strong parallels with psychological phenomenon that describe well known aspects of memory processes. The anatomical and temporal precision of the current study suggests strategies to modulate memory formation and erasure, and will facilitate molecular investigations into the pathways that underlie transitions in synaptic properties during learning and memory.

\section{References}

Abraham WC, Tate WP (1997) Metaplasticity: a new vista across the field of synaptic plasticity. Prog Neurobiol 52:303-323. CrossRef Medline

Anderson JJ, Bradbury MJ, Giracello DR, Chapman DF, Holtz G, Roppe J, King C, Cosford ND, Varney MA (2003) In vivo receptor occupancy of mGlu5 receptor antagonists using the novel radioligand $[3 \mathrm{H}] 3$-methoxy5-(pyridin-2-ylethynyl)pyridine). Eur J Pharmacol 473:35-40. CrossRef Medline

Barrionuevo G, Schottler F, Lynch G (1980) The effects of repetitive low frequency stimulation on control and "potentiated" synaptic responses in the hippocampus. Life Sci 27:2385-2391. CrossRef Medline

Barth AL, Gerkin RC, Dean KL (2004) Alteration of neuronal firing properties after in vivo experience in a FosGFP transgenic mouse. J Neurosci 24:6466-6475. CrossRef Medline

Bashir ZI, Collingridge GL (1994) An investigation of depotentiation of long-term potentiation in the CAl region of the hippocampus. Experimental brain research. Exp Brain Res 100:437-443. CrossRef Medline

Bear MF (1995) Mechanism for a sliding synaptic modification threshold. Neuron 15:1-4. CrossRef Medline

Bender KJ, Allen CB, Bender VA, Feldman DE (2006) Synaptic basis for whisker deprivation-induced synaptic depression in rat somatosensory cortex. J Neurosci 26:4155-4165. CrossRef Medline

Benedetti BL, Glazewski S, Barth AL (2009) Reliable and precise neuronal firing during sensory plasticity in superficial layers of primary somatosensory cortex. J Neurosci 29:11817-11827. CrossRef Medline

Benjamini Y, Hochberg Y (1995) Controlling the false discovery rate: a practical and powerful approach to multiple testing. J R Stat Soc Ser B 57:289-300.

Benuskov á L, Diamond ME, Ebner FF (1994) Dynamic synaptic modification threshold: computational model of experience-dependent plasticity in adult rat barrel cortex. Proc Natl Acad Sci U S A 91:4791-4795. CrossRef Medline

Bienenstock EL, Cooper LN, Munro PW (1982) Theory for the development of neuron selectivity: orientation specificity and binocular interaction in visual cortex. J Neurosci 2:32-48. Medline

Brasier DJ, Feldman DE (2008) Synapse-specific expression of functional presynaptic NMDA receptors in rat somatosensory cortex. J Neurosci 28:2199-2211. CrossRef Medline

Clem RL, Barth A (2006) Pathway-specific trafficking of native AMPARs by in vivo experience. Neuron 49:663-670. CrossRef Medline

Clem RL, Celikel T, Barth AL (2008) Ongoing in vivo experience triggers synaptic metaplasticity in the neocortex. Science 319:101-104. CrossRef Medline

Clem RL, Anggono V, Huganir RL (2010) PICK1 regulates incorporation of calcium-permeable AMPA receptors during cortical synaptic strengthening. J Neurosci 30:6360-6366. CrossRef Medline

Crair MC, Malenka RC (1995) A critical period for long-term potentiation at thalamocortical synapses. Nature 375:325-328. CrossRef Medline

Dachtler J, Hardingham NR, Glazewski S, Wright NF, Blain EJ, Fox K (2011) Experience-dependent plasticity acts via GluR1 and a novel neuronal nitric oxide synthase-dependent synaptic mechanism in adult cortex. J Neurosci 31:11220-11230. CrossRef Medline

Desai NS, Cudmore RH, Nelson SB, Turrigiano GG (2002) Critical periods for experience-dependent synaptic scaling in visual cortex. Nat Neurosci 5:783-789. Medline

Dudai Y (2004) The neurobiology of consolidations, or, how stable is the engram? Annu Rev Psychol 55:51-86. CrossRef Medline

Dudek SM, Bear MF (1992) Homosynaptic long-term depression in area
CA1 of hippocampus and effects of N-methyl-D-aspartate receptor blockade. Proc Natl Acad Sci U S A 89:4363-4367. CrossRef Medline

Feldman DE, Brecht M (2005) Map plasticity in somatosensory cortex. Science 310:810-815. CrossRef Medline

Feldman DE, Nicoll RA, Malenka RC, Isaac JT (1998) Long-term depression at thalamocortical synapses in developing rat somatosensory cortex. Neuron 21:347-357. CrossRef Medline

Finnerty GT, Roberts LS, Connors BW (1999) Sensory experience modifies the short-term dynamics of neocortical synapses. Nature 400:367-371. CrossRef Medline

Fujii S, Saito K, Miyakawa H, Ito K, Kato H (1991) Reversal of long-term potentiation (depotentiation) induced by tetanus stimulation of the input to CA1 neurons of guinea pig hippocampal slices. Brain Res 555:112-122. CrossRef Medline

Glazewski S, Benedetti BL, Barth AL (2007) Ipsilateral whiskers suppress experience-dependent plasticity in the barrel cortex. J Neurosci 27:3910 3920. CrossRef Medline

Goda Y, Stevens CF (1994) Two components of transmitter release at a central synapse. Proc Natl Acad Sci U S A 91:12942-12946. CrossRef Medline

Hardingham N, Wright N, Dachtler J, Fox K (2008) Sensory deprivation unmasks a PKA-dependent synaptic plasticity mechanism that operates in parallel with CaMKII. Neuron 60:861-874. CrossRef Medline

Hensch TK (2005) Critical period plasticity in local cortical circuits. Nat Rev Neurosci 6:877-888. CrossRef Medline

Hou Q, Gilbert J, Man HY (2011) Homeostatic regulation of AMPA receptor trafficking and degradation by light-controlled single-synaptic activation. Neuron 72:806-818. CrossRef Medline

Jacob V, Petreanu L, Wright N, Svoboda K, Fox K (2012) Regular spiking and intrinsic bursting pyramidal cells show orthogonal forms of experience-dependent plasticity in layer $\mathrm{V}$ of barrel cortex. Neuron 73 : 391-404. CrossRef Medline

Jiao Y, Zhang C, Yanagawa Y, Sun QQ (2006) Major effects of sensory experiences on the neocortical inhibitory circuits. J Neurosci 26:8691-8701. CrossRef Medline

Kirkwood A, Dudek SM, Gold JT, Aizenman CD, Bear MF (1993) Common forms of synaptic plasticity in the hippocampus and neocortex in vitro. Science 260:1518-1521. CrossRef Medline

Kirkwood A, Lee HK, Bear MF (1995) Co-regulation of long-term potentiation and experience-dependent synaptic plasticity in visual cortex by age and experience. Nature 375:328-331. CrossRef Medline

Mahan AL, Ressler KJ (2012) Fear conditioning, synaptic plasticity and the amygdala: implications for posttraumatic stress disorder. Trends Neurosci 35:24-35. CrossRef Medline

Malenka RC, Bear MF (2004) LTP and LTD: an embarrassment of riches. Neuron 44:5-21. CrossRef Medline

McClelland JL (1998) Complementary learning systems in the brain. A connectionist approach to explicit and implicit cognition and memory. Ann N Y Acad Sci 843:153-169. CrossRef Medline

Monfils MH, Cowansage KK, Klann E, LeDoux JE (2009) Extinctionreconsolidation boundaries: key to persistent attenuation of fear memories. Science 324:951-955. CrossRef Medline

Myers KM, Ressler KJ, Davis M (2006) Different mechanisms of fear extinction dependent on length of time since fear acquisition. Learn Mem 13: 216-223. CrossRef Medline

Nader K, Schafe GE, LeDoux JE (2000) The labile nature of consolidation theory. Nat Rev Neurosci 1:216-219. CrossRef Medline

O’Brien RJ, Kamboj S, Ehlers MD, Rosen KR, Fischbach GD, Huganir RL (1998) Activity-dependent modulation of synaptic AMPA receptor accumulation. Neuron 21:1067-1078. CrossRef Medline

Philpot BD, Espinosa JS, Bear MF (2003) Evidence for altered NMDA receptor function as a basis for metaplasticity in visual cortex. J Neurosci 23:5583-5588. Medline

Philpot BD, Cho KK, Bear MF (2007) Obligatory role of NR2A for metaplasticity in visual cortex. Neuron 53:495-502. CrossRef Medline

Qi Y, Hu NW, Rowan MJ (2013) Switching off LTP: mGlu and NMDA receptor-dependent novelty exploration-induced depotentiation in the rat hippocampus. Cereb Cortex 23:932-939. CrossRef Medline

Rodríguez-Moreno A, Paulsen O (2008) Spike timing-dependent longterm depression requires presynaptic NMDA receptors. Nat Neurosci 11:744-745. CrossRef Medline

Sutton MA, Wall NR, Aakalu GN, Schuman EM (2004) Regulation of den- 
dritic protein synthesis by miniature synaptic events. Science 304:19791983. CrossRef Medline

Takahashi T, Svoboda K, Malinow R (2003) Experience strengthening transmission by driving AMPA receptors into synapses. Science 299: 1585-1588. CrossRef Medline

Turrigiano GG, Leslie KR, Desai NS, Rutherford LC, Nelson SB (1998) Activity-dependent scaling of quantal amplitude in neocortical neurons. Nature 391:892-896. CrossRef Medline

Villarreal DM, Do V, Haddad E, Derrick BE (2002) NMDA receptor antagonists sustain LTP and spatial memory: active processes mediate LTP decay. Nat Neurosci 5:48-52. CrossRef Medline

Wen JA, Barth AL (2011) Input-specific critical periods for experiencedependent plasticity in layer $2 / 3$ pyramidal neurons. J Neurosci 31 : 4456-4465. CrossRef Medline

Wen JA, Barth AL (2012) Synaptic lability after experience-dependent plasticity is not mediated by calcium-permeable AMPARs. Front Mol Neurosci 5:15. Medline
Whitlock JR, Heynen AJ, Shuler MG, Bear MF (2006) Learning induces long-term potentiation in the hippocampus. Science 313:1093-1097. CrossRef Medline

Wiltgen BJ, Brown RA, Talton LE, Silva AJ (2004) New circuits for old memories: the role of the neocortex in consolidation. Neuron 44:101108. CrossRef Medline

Xu L, Anwyl R, Rowan MJ (1998) Spatial exploration induces a persistent reversal of long-term potentiation in rat hippocampus. Nature 394 891-894. CrossRef Medline

Xu-Friedman MA, Regehr WG (1999) Presynaptic strontium dynamics and synaptic transmission. Biophys J 76:2029-2042. CrossRef Medline

Zhou Q, Tao HW, Poo MM (2003) Reversal and stabilization of synaptic modifications in a developing visual system. Science 300 : 1953-1957. CrossRef Medline 